\title{
On Needs Analysis and College English Teaching in China
}

\author{
Yanping Zheng \\ Foreign Languages Department, North China Institute of Science and Technology, China \\ Email: pyzhengaas@163.com
}

\begin{abstract}
This paper probes into the meaning of a need, the classification of needs and then the term of needs analysis in college English teaching and learning in China. On the basis of this, the author of the paper attaches importance to the needs of college students that should be analyzed in college English teaching in China.
\end{abstract}

Index Terms—need, needs analysis, conformity, college English teaching

The starting point in any teaching program is to determine whether teaching is needed and, if needed, to specify what that teaching should accomplish. So making analysis of the learners' needs is of vital importance to the success of teaching.

\section{WHAT IS A NEED?}

Different scholars (Munby,1978: 43; Berwick,1989:57; Howatt,1984:245; Widdowson, 1981:2 )have done certain research concerning needs and needs analysis. A need has been described as:

A gap between "what is" and "what should be." (Witkin et al., 1995)

"A gap between real and ideal that is both acknowledged by community values and potentially amenable to change." (Reviere, 1996, p. 5)

May be different from such related concepts as wants ("something people are willing to pay for") or demands ("something people are willing to march for"). (McKillip, 1987)

Lefrancois $(2004,291)$ points out in brief that need is "a lack that gives rise to a desire for satisfaction".

It can be seen that Lefrancois presents the easiest explanation of the term.

\section{THE CLASSIFIATIONS OF NEEDS}

Different classifications of needs have been put forward so far. Brindley (1989:76),for example, refers to a study in which three different teacher orientations to students' needs are found: a general-language-proficiency view of needs, a psychological/humanistic view, emphasizing learners' affective and strategic needs, and specific-purpose-view, emphasizing instrumental needs. Here Brindley lays emphasis on curriculum planning and reconciling, involving what learners want and what teachers think the learners need.

Munby' instruments directed at target needs, i.e. the needs that a learner will have when performing his specific work-tasks, at the end of the language course. Such needs have been studied extensively.

Tom Hutchinson and Alan Waters (1991:53-63) have done thorough research in analyzing needs. They make a basic distinction between target needs and learning needs. Then they make further division within the categories of target needs and learning needs. Target needs refer to what the learners need to do in target situation. A needs analysis, which focuses on the learners' needs at the end of a language course, can be called a target situation. Target needs are something of an umbrella term (a general term), which in practice comprises certain important distinctions. And target situation can be analyzed in terms of necessities (what the learners have to know in order to function effectively in the target situation), lacks (which of the necessities the learners lack) and wants (what the learners themselves need to obtain). Learning needs refer to what the learners need to do in order to learn English.

It can be seen that such classifications of needs are precise and clear, and can be applicable in various fields or subjects.

Needs can also be classified into the learners' needs, the teachers' needs and the administrators' needs (Masuhara, 1998: 239-260). It is noticeable that the three kinds of needs are not entirely the same. There is certain gap between each other. The learners' needs are independent of teachers and can not be satisfied or taught by teachers. And the learners would not appreciate the teachers' needs. What's more, Masuhara is aware that the learners' needs maybe do not really reflect the learner' real needs. Further study is needed on how to balance the three needs. Such classification is made from the perspectives of different subjects.

Mackey and Mountford (1978:28) thinks that needs of the learners may be roughly divided into academic needs(where English is required for further academic study)and job needs (where English is required in order to perform a particular job). The learners will have the latter needs in future, but not now. And their answers(if they are 
asked) to needs will probably be different for students are different and their needs are always changing as well. This way of classification is absolutely not so delicate.

Lefrancois (2004: 291)maintains that needs fall into such categories as physiological needs (which include the need for food, drink, sex and the need to maintain body temperature) and psychological needs (the needs for affection, belonging, achievement, independence, social recognition and self-esteem).

From the above mentioned points, it is clear that needs are various and can be diversified out of different subjects. Thus, needs analysis should be differentiated depending on various groups and different purposes.

\section{WhAT IS NEEDS ANALYSIS?}

As to the term needs analysis, certain researches have been done by some scholars. Munby (1978: 43) holds the view that needs analysis is designed to make it possible to adjust language courses to the needs of groups of students working on various countries at different levels of proficiency and with a variety of objectives in mind.

Richards, Platt and Weber (1985), in their study of needs analysis, maintained that needs analysis is to know and identify the language learners' needs and the process of arranging the learning needs by its importance. Thus, it can be said that needs analysis is to learn why the learners study language, what aspects of language they need to study and what degree they need to study, etc.

And it is indicated by Tarone and Yule (2000:31) that needs analysis refers to investigating the language learner's needs. The term needs analysis once used in the context of language instruction has usually referred to the collection and evaluation of information to answer the question: "What aspects of the language do learners need to know?" It is impossible, for a variety of reasons, not the least of which is lack of time, to teach all of any language. Needs analysis involves selections but not all the selections are particularly effective.

Mitchell (1993) describes needs analysis as "an examination of the existing need for training within an organization". In other words, it identifies performance areas or programs within an organization where training or teaching should be applied. A needs analysis gathers information about present practices and compares these practices to the desired way of doing business or teaching and learning. The difference between where you are now and where you want to be defines where a teaching or training program should concentrate its effort.

This information also establishes a baseline against which teaching or training accomplishments can be measured. If you know where you start, it is easier to determine if your teaching or training has been effective.

A needs analysis may identify more than one learning or training need. These needs should be prioritized, and either placed into a formal teaching or training plan, or form a data base for future teaching or training.

In simplest terms, a needs analysis includes all the activities used to collect information about the students' learning needs, wants, wishes, desires, etc... The process also sometimes involves looking at the expectations and requirements of other interested parties such as the teacher/teacher's aid/ tutor (you), administrators, financial supporters, and other people who may be impacted by the program (such as students' family members or employers). A needs analysis can be very formal, extensive and time consuming, or it can be informal, narrowly focused and quick. Some of resources for conducting a needs analysis may include surveys and questionnaires, test scores, and interviews.

In essence, need analysis is the process of identifying and evaluating needs in a community or other defined population of people. The identification of needs is a process of describing "problems" of a target population and possible solutions to these problems. It focuses on the future, or what should be done, rather than on what was done as is the focus of most program evaluations.

\section{NeEds Analysis And COLLEGE ENGlsih TEACHING IN CHINA}

A large number of college students in China have learned English as one of foreign languages. Some of them are successful learners, while more of them have encountered difficulties. It is necessary for language instructors to help those learners who have problems in their learning. And the initial step to solve the problems of the students is to identify the needs of the students.

Here the needs of students is the only element that is mentioned instead of other parties such as the teacher/teacher's aid/ tutor, administrators, financial supporters, and other people who may be impacted by the program (such as students' family members or employers). The reason is that English (Japanese or Russian for some students) is a compulsory course in the first three or four terms of most of the students' college study in China. The state, the instructors, the prospective employers and the family members have the common sense in this matter. Therefore, the focus is on the learners, i.e., the college students.

What kind of needs should be analyzed among college students in China? Brindley (1989) and Robinson (1991) present such set of concepts as objective needs and subjective needs. Objective needs refer to all the objective conditions of the language learners such as their current level, difficulties in language learning. While subjective needs refer to the cognitive and affective needs of the language learners such as self-esteem and attitude.

Both objective needs and subjective needs should be analyzed among Chinese college students. And it is advisable to give priority to analyzing the subjective needs of the college students in terms of language study. For conformity exists 
in the minds of most college students. And it would affect the learning activities of the students greatly, especially, when the students have classes in groups of more than seventy, which is the usual case in colleges and universities.

Then the objective needs of the college students can be analyzed, i.e., target needs and learning needs of the college students. And their learning needs can be analyzed in great detail so as to solve the problems of the students in English learning more thoroughly.

In a word, analyzing the students' needs is the initial step and the key step in the whole process of college English teaching in China. It is also conducive for language instructors to select teaching materials, to determine teaching strategies and to make other relevant decisions concerning college English teaching.

\section{REFERENCES}

[1] Berwick, R. (1989). Needs Assessment in Language Programming: From Theory to Practice. In Johnson, R. K (ed). The Second Language Curriculum. Cambridge: Cambridge University Press,.

[2] Brindley, G. (1989). The Role of Needs Analysis in Adult ESL Program Design. In R. K. Johnson ,ed. The Second Language Curriculum. Cambridge: Cambridge University Press.

[3] Howatt, A. (1984). A History of English Language Teaching. Oxford: OUP.

[4] Hutchinson, T. and Waters, A., (1991). English For Specific Purposes (A Learning Centred Approach), New Directions in Language Teaching, Cambridge: Cambridge University Press.

[5] Lefrancois, Guy R. (2004). Theories of Human Learning, Beijing: Foreign Language Teaching and Research Press.

[6] Mackey,R. and Mountford, Alan. (1978). English for Specific Purpose: a case study approach, London: Longman.

[7] McKillip, J. (1987). Need Analysis: Tools for the Human Service and Education. Applied Social Research Methods Series, Volume 10. Sage Publications: Thousand Oaks, CA.

[8] Mitchell, G. (1993). The Trainer's Handbook, The AMA Guide to Effective Training, 2nd Edit. AMACOM, NY, 423 pp.

[9] Munby, J. (1978). Communicative Syllabus Design: A Sociolinguistic Model for Defining the Content of Purpose-Specific Language Programs. Cambridge: Cambridge University Press.

[10] Reviere, R., Berkowitz, S., Carter, C.C., Gergusan, C.G. (Eds) (1996). Needs Assessment: A Creative and Practical Guide for Social Scientists. Taylor and Francis: Washington, DC.

[11] Richards,J., Platt, J., and Weber, H. (1985). Longman Dictionary of Applied Linguistics, Longman.

[12] Robinson, P. (1991). ESP Today: A Practitioner's Guide, Prentice Hall International (UK) ltd.

[13] Tarone, Elaine and Yule, George. (2000). Focus on the Language Learner. Shanghai: Shanghai Foreign Language Education Press.

[14] Widdowson, H.G. (1981). English for specific purposes: Criteria for course design. In L. Selinker, E. Tarone, and V. Hanzedi (eds.) English for Academic and Technical Purposes: Studies in Honor of Louis Trimble. New York: Newbury House.

[15] Witkin, B. R. and Altschuld, J. W. (1995). Planning and Conducting Needs Assessments: A Practical Guide. Sage Publications: Thousand Oaks, CA.

Yanping Zheng was born in Jingmen, Hubei province, China in 1969. He received his M.A degree in Beijing International Studies University, China in 2005. And he has been working for his doctoral degree in Shanghai Foreign Language Studies University

$\mathrm{He}$ is currently an associate professor in Foreign Languages Department of North China Institute of Science and Technology, East of Beijing, China. His research interests include second language acquisition and translation studies. 